20 Gruppo Italiano per lo Studio della Streptochinasi nell'Infarto Miocardico (GISSI). Effectiveness of intravenous thrombolytic treatment in acute myocardial infarction. Lancet 1986 ; i:397-402.

21 Fibrinolytic Therapy Trialists' (FTT) Collaborative Group. Indications for fibrinolytic therapy in suspected acute myocardial infarction: collaborative overview of early mortality and major morbidity results from all randomised trials of more than 1000 patients. Lancet 1994;343:311-22.

22 Gomez-Marin O, Folsom AR, Kottke TE, Wu SC, Jacobs DRJ, Gillum RF, et al. Improvement in long-term survival among patients hospitalized with acute myocardial infarction, 1970 to 1980 . The Minnesota heart survey. N Engl I Med 1987;316:1353-9.

23 Bueno H, Vidan T, Almazan A, Lopez-Sendon J, Delcan J. Influence of sex on short-term outcome of elderly patients with a first acute myocardial on short-term outcome of elderly patients

24 Every N, Maynard C, Hallstrom A, Martin J, Parson S, Weaver W. Long-term survival in 11,000 consecutive patients with AMI. Circulation 1995;92(suppl):1-27.

25 Danish Multicenter Study Group. Verapamil in acute myocardial infarction. Eur Hear $\mathcal{f} 1984 ; 5: 516-28$.

26 Rose GA, Blackburn H, Gillum RF, Preineas AJ. Cardiovascular survey methods. Geneva: World Health Organisation, 1982. (Monograph Series.)

27 Thomsen BL. $A$ note on the modelling of continuous covariates in Cox regression model. Copenhagen: Statistical research unit, University of Copenhagen. 1988. (Research report 88/5:3-17.)

28 Launbjerg J, Fruergaard P, Jacobsen HL, Utne HE, Reiber J, Madsen JK. The long-term predictive value of an exercise thallium-201 scintigraphy for patients with acute chest pain but without myocardial infarction. Coron Artery Dis 1993;4:195-200.

29 Launbjerg J, Fruergaard P, Jacobsen HL, Madsen JK. Risk factors related to the 7-year prognosis for patients suspected of myocardial infarction with and without confirmed diagnosis. Cardiology 1992;80:294-301.

30 Lerman A, Hildebrand FLJ, Aarhus LL, Burnett JCJ. Endothelin has biological actions at pathophysiological concentrations. Circulation 1991; 83:1808-14.

31 Edwards BS, Hunt SA, Fowler MB, Valantine HA, Anderson LM, Lerman A. Effect of cyclosporin on plasma endothelin levels in humans after cardiac transplantarion. Am I Cardiol 1991;67:782-4.

32 Isles CG, Hole DJ, Hawthorne VM, Lever AF. Relation between coronary risk and coronary mortality in women of the Renfrew and Paisley survey:
ristion risk and coronary mortality in women of the Renfison with men. Lancet 1992;339:702-6.

33 Wilson PW, Garrison RJ, Castelli WP. Postmenopausal, estrogen use, cigarette smoking and cardiovascular disease in women over 50 . The Framingham study. $N$ Engl $f$ Med 1985;313:1038-43

34 AIMS Trial Study Group. Effect of intravenous APSAC on mortality after acute myocardial infarction: preliminary report of a placebo-controlled clinical trial. Lancet 1988;i:545-9.

35 Launbjerg J, Fruergaard P, Madsen JK, Hansen JF. Three-year mortality in patients suspected of acute myocardial infarction with and without confirmed diagnosis. The Danish Study Group on verapamil in myocardial infarction. Am Heart f 1991;122:1270-3.

(Accepted 18 April 1996)

\title{
Efficacy of a small single dose of oral dexamethasone for outpatient croup: a double blind placebo controlled clinical trial
}

\author{
G C Geelhoed, J Turner, W B G Macdonald
}

Abstract
Objective-To assess the efficacy of a single dose of oral dexamethasone $0.15 \mathrm{mg} / \mathrm{kg}$ in children with mild croup not admitted to hospital.

Design-Double blind, randomised, placebo controlled clinical trial.

Setting-The emergency department of a tertiary paediatric hospital.

Subjects-100 children aged 4-122 months presenting with mild croup.

Intervention-A single oral dose of dexamethasone $0.15 \mathrm{mg} / \mathrm{kg}$ or placebo.

Main outcome measure-Return to medical care with ongoing croup.

Results-Baseline characteristics of the two treatment groups were similar. Eight children (all from the placebo group) returned to medical care with ongoing croup, one being admitted. There was no reported difference in duration of croup symptoms, duration of viral symptoms, or rate of return to medical care for other reasons.

Conclusion-Oral dexamethasone in a dose of $0.15 \mathrm{mg} / \mathrm{kg}$ is effective in reducing return to medical care with ongoing croup in children with mild croup.

\section{Introduction}

Croup (acute laryngotracheobronchitis) is one of the more common childhood respiratory illnesses. Children with moderate to severe airway obstruction are traditionally admitted to hospital for observation. Corticosteroids are now often used for children hospitalised with croup, though the role of steroids for children with less severe illness who are not admitted to hospital has not been studied in depth. A survey of 112 paediatricians and family practitioners from the United States showed that 104 used steroids in children hospitalised with croup, though only 48 used steroids "always." By contrast, four used steroids "always" for outpatients whereas 36 "never" used them. ${ }^{1}$ Only one study has looked for benefit from steroids in children not hospitalised with croup. ${ }^{2}$ The small numbers in that study suggested but could not show conclusively that steroids were of benefit in preventing reattendance with croup.
A recent study from this hospital showed that both nebulised budesonide and oral dexamethasone (0.6 $\mathrm{mg} / \mathrm{kg}$ ) were more effective than placebo in reducing the duration of hospitalisation, croup scores, and need for nebulised adrenaline more than one hour after hospital admission. ${ }^{3}$ We subsequently showed that a smaller dose of dexamethasone $(0.15 \mathrm{mg} / \mathrm{kg})$ was as effective as 0.3 or $0.6 \mathrm{mg} / \mathrm{kg}^{4}$

Because of the obvious benefits of steroids in children admitted to hospital with croup we proposed that steroids might also benefit children with croup who attend hospital emergency departments but are not admitted. Historically, 1800 to 2000 cases of croup present to our emergency department every year. Three quarters of these children are not admitted, though $10-15 \%$ subsequently present to medical care with ongoing croup. We hypothesised that a single oral dose of dexamethasone $0.15 \mathrm{mg} / \mathrm{kg}$ would be of benefit to children with milder croup who were not admitted to hospital.

\section{Patients and methods}

Children older than 3 months with no other acute or chronic medical problem were eligible for the study if they presented to the emergency department with a diagnosis of croup not severe enough to warrant admission. Croup was defined as the acute onset of inspiratory stridor, chest wall retractions, barking cough, and hoarseness. Generally only children with croup who have stridor and chest wall retractions at rest are admitted to our hospital, those with milder illness being discharged home at the discretion of medical staff. Children were excluded if their families did not have a telephone or had limited English; if they had received steroids of any description in the preceding week; or if they had a pre-existing upper airway condition, a history of prolonged stridor, or a clinical picture suggesting a diagnosis other than croup. Informed written consent was obtained from parents and the study approved by the hospital's ethics committee.

After enrolment the parents completed a questionnaire asking about current and past episodes of croup. Croup score (see box), pulse rate, and respiratory rate at presentation were recorded together with arterial oxygen saturation from a finger probe in room air by 
Table 1-Baseline characteristics of 100 children with mild croup treated with steroid or placebo. Except where stated otherwise values are means (SD)

\begin{tabular}{lcc}
\hline & Steroid & Placebo \\
\hline No studied & 50 & 50 \\
No male/No female & $34 / 16$ & $36 / 14$ \\
Age (months) & $37(23)$ & $45(26)$ \\
Duration of symptoms (hours) & $19(34)$ & $21(54)$ \\
Temperature $\left({ }^{\circ} \mathrm{C}\right)$ & $37.1(0.8)$ & $37.1(0.9)$ \\
Pulse (rate/min) & $133(23)$ & $126(22)$ \\
Respiratory (rate/min) & $29(6)$ & $29(6)$ \\
Arterial oxygen saturation (\%) & $98.2(1.4)$ & $98.4(1.3)$ \\
Initial croup score & 0.9 & 0.9 \\
No with previous history of croup & 18 & 15 \\
\hline
\end{tabular}

Table 2-Outcome measures for 100 children with mild croup treated with steroid or placebo. Except where stated otherwise values are means (SD)

\begin{tabular}{llll}
\hline & Steroid & Placebo & Significance \\
\hline $\begin{array}{l}\text { No followed upt } \\
\begin{array}{l}\text { No who reattended with } \\
\text { croup }\end{array}\end{array}$ & 48 & 48 & \\
$\begin{array}{l}\text { No admitted with croup } \\
\begin{array}{c}\text { Duration of croup } \\
\text { symptoms (days) }\end{array}\end{array}$ & 0 & 8 & P<0.01 \\
$\begin{array}{c}\text { Duration of viral } \\
\text { symptoms (days) }\end{array}$ & $6.5(4.4)$ & $6.7(4.2)$ & NS \\
$\begin{array}{c}\text { No who reattended for } \\
\text { other reasons }\end{array}$ & 18 & 18 & NS \\
\hline
\end{tabular}

tFour children were not followed up. NS $=$ Not significant.

means of a Nellcor N-100 pulse oximeter (Nellcor Inc, Hayward, California). Subjects were then randomised to receive either oral dexamethasone $0.15 \mathrm{mg} / \mathrm{kg}$ or placebo. Treatments were given double blind.

Seven to 10 days after discharge the children's parents were contacted by telephone. The principal outcome measure was return to medical care with ongoing croup. We also inquired about admissions to hospital with ongoing croup, duration of croup symptoms, duration of viral symptoms, and whether the child had presented to medical care for any other reason.

Mean croup scores were compared by MannWhitney $U$ test for non-parametric ordinal data, the remaining normally distributed observations being compared by unpaired Student's $t$ test. We calculated that a sample size of $\mathbf{8 8}$ was required to achieve $80 \%$ power to show a $90 \%$ reduction in the reattendance rate for ongoing croup in steroid treated children $(\alpha=0.05)$.

\section{Results}

One hundred children were enrolled in the trial. Most instances of failure to enrol were due to refusal by parents. Children not enrolled showed no difference from the study population in any variable, including severity of croup. The children's ages ranged from 4 to 122 months, 90 being under 6 years of age. Baseline characteristics of the two treatment groups were similar (table 1). Ninety six of the 100 families were contacted after discharge from the emergency department.

Reattendance with croup after discharge-Eight children, all from the placebo group, subsequently attended a medical facility for croup after discharge $(P<0.01$; table 2). No child treated with steroids required further medical care for croup.

Other parameters-There was no difference between the groups in admission to hospital with ongoing croup, duration of croup symptoms, duration of viral symptoms, and proportion returning to medical care for any other reason (table 2 ).
Discussion

In this trial oral dexamethasone $0.15 \mathrm{mg} / \mathrm{kg}$ significantly reduced the number of children with mild croup who reattended for medical care with ongoing croup. Meta-analysis of the nine methodologically satisfactory studies conducted up to 1989 suggested that steroid therapy was associated with clinical improvement for children hospitalised with croup. ${ }^{5}$ Other studies of inhaled and parenteral steroids in children admitted to hospital with croup have all shown benefit from treatment. ${ }^{346-8}$

DEXAMETHASONE VERSUS BUDESONIDE

Three studies have shown a nebulised steroid, budesonide, to be beneficial in croup, ${ }^{389}$ two finding a reduction in the duration of hospitalisation. One of these studies, from our hospital, ${ }^{3}$ also showed that budesonide $(2 \mathrm{mg})$ and oral dexamethasone $(0.6 \mathrm{mg} / \mathrm{kg})$ were more effective than placebo, with reduced hospitalisation time, reduction in croup scores compared with placebo from one hour, and reduced need for nebulised adrenaline after one hour. Though there were no significant differences in the efficacy of oral dexamethasone or nebulised budesonide in this study, there was a consistent trend in favour of the oral preparation. Also, it was our impression that an oral agent (whether placebo or active drug) was easier to give to distressed young children than was a nebulised preparation.

Dexamethasone is also cheaper than nebulised budesonide and requires no additional equipment such as facemask and tubing. Hence the practice in our emergency department is to use oral dexamethasone rather than budesonide.

\section{PAST STUDIES IN MILD CROUP}

Only one study of dexamethasone $0.6 \mathrm{mg} / \mathrm{kg}$ intramuscularly has looked for benefit from steroids in children not admitted to hospital with croup. ${ }^{1}$ Of a total of 38 children, five returned to medical care with ongoing croup, four of the five having received placebo. Because of small numbers the study could not show conclusively that steroids were of benefit in preventing reattendance with croup. Parents, however, reported a substantial improvement in children treated with steroids at 24 hours, though the overall time to resolution of symptoms was unchanged. Our study used more appropriate numbers, a less expensive and less painful mode of administration, and a quarter of the dose. Both studies found that times to overall resolution of croup symptoms and viral symptoms were not different between the steroid and placebo groups. We did not ask about the severity of croup symptoms at any time but presumably these were less severe, as no parent of a steroid treated child sought medical help for croup whereas $16 \%$ of the placebo group did so.

\section{CROUP SCORE}

A clinical scoring system is not the ideal means of assessing response to a therapeutic intervention, but other means of doing so are not practical in croup. Clinical scoring systems are a well established means of evaluating

\begin{tabular}{|c|c|}
\hline \multicolumn{2}{|l|}{ Croup score } \\
\hline & Score \\
\hline \multicolumn{2}{|l|}{ Stridor } \\
\hline None & 0 \\
\hline Only on crying, exertion & 1 \\
\hline At rest & 2 \\
\hline Severe (biphasic) & 3 \\
\hline \multicolumn{2}{|l|}{ Retractions } \\
\hline None & 0 \\
\hline Only on crying, exertion & 1 \\
\hline At rest & 2 \\
\hline Severe (biphasic) & 3 \\
\hline
\end{tabular}




\section{Key messages}

- Croup is a common presenting problem in paediatric emergency departments

- The benefits of steroids for children admitted to hospital are now well established

- Most children with croup may be sent home, though up to one fifth may return with croup

- A small single dose of oral dexamethasone $(0.15 \mathrm{mg} / \mathrm{kg})$ dramatically reduces the chance of reattending

- All children presenting with croup should be considered for steroids therapeutic interventions in croup. ${ }^{6}{ }^{10}{ }^{11}$ The croup score used in this study differed from that used in other studies in that we did not include measures for degree of restlessness or cyanosis. These conditions are difficult to standardise and are seen primarily in children with very severe croup, who were excluded from our study.

Also a subjective assessment of cyanosis was not necessary in our study, as all children were monitored at presentation with pulse oximetry. As reported in our earlier work, to ensure an acceptable level of interobserver agreement for our modified croup score a score was blindly assigned prospectively by two workers to 15 randomly selected children with croup not in the trial. ${ }^{4}$ The weighted $K$ statistic was $\mathbf{0 . 8 7}$, indicating acceptable interobserver agreement.

SPASMODIC CROUP

As in our earlier studies, we did not attempt to distinguish viral from spasmodic croup, as it is often difficult to make this distinction in practice and definitions of viral and spasmodic croup vary. Studies have shown improvement after steroid administration in both viral $^{7}$ and spasmodic ${ }^{612}$ croup, though other investigators have not distinguished between the two entities. ${ }^{1013}$ Many children presenting in our study had features to suggest both viral (for example, fever and rhinorrhoea) and spasmodic (for example, recurrent episodes) aetiologies, and some workers argue that the two conditions lie at each extreme of a continuous spectrum..$^{14}$

\section{EVIDENT BENEFITS OUTWEIGH POTENTIAL HARM}

There has been reluctance in the past to use steroids for croup, even for hospitalised children, partly owing to a lack of acceptable evidence. Secondly, there is an often stated feeling that croup is a benign self limiting condition and that steroids are potentially harmful. This argument especially applied to children with milder croup who were not admitted to hospital and when no definite benefits were known. Our results provide evidence of such benefits. Also it must be remembered that even mild croup can develop into a very frightening condition and that as many as $10-15 \%$ of children who present to emergency departments and are sent home return to medical care because of parental concern.

During this study one child from the placebo group was considered worrying enough to be admitted to hospital after reattendance. Though the merits of using any medication must be carefully considered, it is worth remembering that it is routine to give up to five to 10 times the equivalent dose of steroids over several days to children with mild asthma attacks who present to emergency departments and are not admitted.

In summary, we have shown that using oral dexamethasone in a dose of $0.15 \mathrm{mg} / \mathrm{kg}$ in a paediatricemergency department is effective in reducing the reattendance of children with mild croup.

We thank Mr David McKnight and the staff of the pharmacy for their help and support in setting up this study and the staff of the emergency department, who participated so enthusiastically.

Funding: Departmental budget only.

Conflict of interest: None.

1 Connors K, Gavula D, Terndrup T. The use of corticosteroids in croup: a survey. Pediatr Emerg Care 1994;4:197-9.

2 Cruz MN, Stewart G, Rosenberg N. Use of dexamethasone in the outpatient management of acute laryngotracheitis. Pediatrics 1995;96:220-3.

3 Geelhoed GC, Macdonald WBG. Oral and inhaled steroids in croup: a randomized, placebo-controlled trial. Pediatr Pulmonol (in press)

4 Geelhoed GC, Macdonald WBG. Oral dexamethasone in the treatment of croup: $0.15 \mathrm{mg} / \mathrm{kg}$ versus $0.3 \mathrm{mg} / \mathrm{kg}$ versus $0.6 \mathrm{mg} / \mathrm{kg}$. Pediatr Pulmonol (in press).

5 Kairys SW, Olmstead EM, O'Connor GT. Steroid treatment of laryngotracheitis: a meta-analysis of the evidence of randomized trials. Pediatrics 1989;83:683-93.

6 Kuusela A, Vesikari T. A randomized, double-blind, placebo-controlled trial of dexamethasone and racemic epinephrine in the treatment of croup. Acta Paediatrica Scandinavica 1988;77:99-104.

7 Super DM, Cartelli NA, Brooks LJ, Lembo RM, Kumar ML. A prospective randomized double-blind study to evaluate the effect of dexamethasone in acute laryngotracheitis. I Pediatr 1989;115:323-9.

8 Husby S, Agertoft L, Mortensen S, Pedersen S. Treatment of croup with nebulised steroid (budesonide): a double blind, placebo controlled study. Arch Dis Child 1993;68:352-5.

9 Klassen TP, Feldman ME, Watters LK, Sutcliffe T, Rowe PC. Nebulized budesonide for children with mild to moderate croup. $N$ Engl $₹$ Med 1994;331:285-9.

10 Leipzig B, Oski FA, Cummings CW, Stockman JA, Swender P. A prospective randomized study to determine the efficacy of steroids in the treatment of croup. I Pediatr 1979;94:194-6.

11 Muhlendahl KE v, Kahn D, Spohr HL, Dressler F. Steroid treatment in pseudo-croup. Helvetica Paediatrica Acta 1982;37:431-6.

12 Koren G, Frand M, Barzilay Z, MacLeod SM. Corticosteroid treatment of laryngotracheitis $\mathrm{v}$ spasmodic croup in children. $A m$ f Dis Child 1983;137:941-4.

13 James JA. Dexamethasone in croup. Am $\mathcal{F}$ Dis Child 1969;117:511-6.

14 Westley CR, Cotton EK, Brooks JG. Nebulized racemic epinephrine by IPPB for the treatment of croup. Am $₹$ Dis Child 1978;132:484-7.

15 Novik A. Corticosteroid treatment of non-diphtheritic croup. Acta Otolaryngol (Stockh) 1960;158(suppl):20-2.

(Accepted 3 Fune 1996)

\section{A MEMORABLE PATIENT}

\section{A palpable success}

Many years ago a young mother came to see me. At the end of the consultation she made one of those "seeing I'm here, doctor" requests for me to look at her baby's nappy rash. Normally I would deal with this while the baby sat on the mother's knee, but for some reason I asked her to lay the baby on the examination couch. On partially unclothing the baby I was able, quite easily, to confirm the mother's diagnosis. While discussing the management of the rash I, almost absentmindedly, laid my hand on the baby's abdomen-probably to soothe my little patient. I was amazed and appalled to feel a mass occupying almost half of the left hand side of the abdominal cavity. I immediately referred the baby to the paediatric hospital department with a gentle and, I hope, diplomatic suggestion that palpation of the baby's abdomen should be kept to the absolute minimum. The following day a large Wilm's tumour was successfully removed.

Some years later my young patient proudly presented me with a first year school photograph. This lay in the top drawer of my desk for many years until I retired a few years ago.

I often wondered what the outcome would have been had I not so fortuitously and almost casually laid my hand on the baby's tummy. - W F PAVELEY is a retired general practitioner in Derby 